\title{
CORRESPONDENCE
}

\section{Coexisting chloritoid and staurolite}

SIR,-It is with surprise that we read in a paper by Fox $(1971$, p. 210):

'Details of the analytical procedure used can be obtained from Schrijver \& Maclean (Unpublished manuscript McGill University, 1970).'

We wish to make it clear that we do know little more about the details of $\mathrm{Mr}$ Fox's analytical procedure than that 'ten 10-second counts were taken on both the standard and the unknown' (Fox, 1970, p. 16).

Our (Schrijver \& Maclean's) experimental work, referred to by $\mathrm{Mr}$ Fox, was designed to test the stability of the ACTON-CAMECA electron microprobe and to assess the 'operator' component of variance in simple, routine manipulation of the instrument. We obtained the expression

where

$$
n=k \cdot\left(x^{p}+y^{p}\right) \cdot 10^{4},
$$

$n=$ sample size (number of 10-second count intervals) required for a $95 \%$ con-

fidence interval of $2 \%$ of the average ratio of peak intensities of 'unknown' $(x)$ and and

'standard' $(y)$,

$k$ and $p$ are constants characteristic of the electronic gear used (e.g. spectrometer), operator and, perhaps, of the particular $\mathrm{x}$-ray signal received.

Thus the expression (1) does not take into account the variance component due to sample heterogeneity. Moreover, it is applicable only to maior elements and, as far as we know, only to one particular operator (W. H. MacLean).

In the ideal case where 'unknown' and 'standard' (i) are perfectly homogeneous and (ii) are of identical composition and structure, substitution of the appropriate constants in (1) gives values for $n$ of the order of 10 .

Clearly, these values do not apply to Mr Fox's analytical work. It must remain a question whether the unknown precision and accuracy of Fox's analyses (1971, Tables 1 to 4) would affect his petrological conclusions.

\section{References}

Fox, J. S. 1970. Petrologic study of chloritoid and staurolite bearing rocks, Agnew Lake, Ontario. Unpublished M.Sc. thesis, McGill University, Montreal.

1971. Coexisting chloritoid and staurolite and the staurolite-chlorite isograd from the Agnew Lake area, Ontario. Geol. Mag. 108, 205-219.

Schrijver, K. \& MacLean, W. H. 1970. Statistics of count rates and ratios of count rates in electron-microprobe analysis. Unpublished manuscript, Dept. Geol. Sci., McGill University, Montreal, P.Q.

K. SCHRIJVER AND W. H. MACLEAN

Dept. Geol. Sciences

McGill University

Montreal, P.Q.

Canada

12th January 1972

SIR,-I wish to apologize to $\mathrm{Mr}$ Schrijver and $\mathrm{Dr}$ Maclean for the imprecise reference to their unpublished work in my recent paper (Fox, 1971). The sentence in question should be corrected to read as follows:

'Details of the correction program used in the analysis can be obtained from Schrijver \& Maclean (1970). The operating conditions and the analytical procedure are described by Fox (1970).'

In response to the criticisms of Mr Schrijver and Dr Maclean I have re-analysed the staurolite, chloritoid and chlorite from sample W-1 with a Cambridge Scientific 
Instruments Geoscan electron microprobe. The microprobe was operated at an acceleration voltage of $20 \mathrm{kV}$ and a specimen current of 30 nanoamperes; this department's T.I.M. 2 computer program was used to correct the raw data. The analyses are presented below.

$\begin{array}{lccc} & \text { staurolite } & \text { chloritoid } & \text { chlorite } \\ \mathrm{Al}_{2} \mathrm{O}_{3} & 55.47 & 40.99 & 23.72 \\ \mathrm{FeO} & 12.57 & 23.49 & 26.88 \\ \mathrm{TiO}_{2} & 00.56 & 00.02 & 00.05 \\ \mathrm{MgO} & 01.04 & 02.95 & 13.59 \\ \mathrm{SiO} & 27.40 & 24.52 & 23.77 \\ \mathrm{ZnO} & 00.74 & 00.05 & 00.03 \\ \mathrm{MnO} & 00.25 & 00.41 & \underline{00.14} \\ \text { anhydrous } & & & \\ \text { total } & 98.03 & 92.43 & 88.18 \\ & & & \\ \mathrm{Al} & 18.062 & 3.974 & 5.912 \\ \mathrm{Fe} & 2.904 & 1.616 & 4.752 \\ \mathrm{Ti} & 0.116 & 0.002 & 0.009 \\ \mathrm{Mg} & 0.427 & 0.362 & 4.283 \\ \mathrm{Si} & 7.569 & 2.016 & 5.026 \\ \mathrm{Zn} & 0.151 & 0.003 & 0.005 \\ \mathrm{Mn} & 0.058 & 0.029 & 0.025 \\ \mathrm{H} & 4.000 & 4.000 & 16.000 \\ \mathrm{O} & 48.000 & 14.000 & 36.000\end{array}$

It is apparent that although different instruments, operating conditions, standards and correction programs were used to obtain these values and those presented in Fox (1971) the two groups of analyses are definitely comparable. The analyses published in that paper thus appear to be reproducible within reasonable limits.

The new data confirm that staurolite $\mathrm{W}-1$ is richer in $\mathrm{Al}_{2} \mathrm{O}_{3}$ and poorer in $\mathrm{FeO}$ than seems common for this mineral. I had originally questioned the accuracy of my analysis and had invoked standard inhomogeneity to explain the phenomenon but this now seems unnecessary. It might be interesting to note in this regard that $I$ have recently analysed another staurolite (staurolite 91229, Bannock Hill, Kincardineshire: see Chinner, 1967) with $\mathrm{FeO}, \mathrm{MgO}, \mathrm{Al}_{2} \mathrm{O}_{3}$ and $\mathrm{SiO}_{2}$ values very similar to those of staurolite W-1.

Finally, when these new analyses, together with the previously published analyses of the ilmenite, rutile and andalusite from W-1 are re-calculated according to the method outlined in the paper, the following reaction is obtained:

\section{$1.727 \mathrm{ctd}+0.012 \mathrm{rut}+0.044 \mathrm{ilm}+5.000 \mathrm{and}=0.911 \mathrm{st}+0.055 \mathrm{chl}+1.362 \mathrm{qtz}+1.192 \mathrm{H}_{2} \mathrm{O}$}

( $\mathrm{ZnO}$ residual of 0.133 moles, consumed).

The coefficients of this reaction can be seen to be of the same order as those of reaction 11 in Fox (1971). In particular, it is clear that chlorite remains a prograde reaction product. The analyses presented in the paper are thus not open to question and the conclusions reached in it still stand.

Reference (Additional to those previously listed)

Chinner, G. A. 1967. Chloritoid, and the isochemical character of Barrow's zones. J. Petrology 8, 268-82.

J. S. FOX

Department of Mineralogy and Petrology

Cambridge University

Downing Place, Cambridge

27th March 1972 